\title{
Towards an integrated approach for red mud valorisation: a focus on titanium
}

\author{
M. Pietrantonio ${ }^{1}$ - S. Pucciarmati ${ }^{1}$ - G. N. Torelli $^{2}$ - G. D'Aria ${ }^{1}$ - F. Forte ${ }^{1}$ - D. Fontana ${ }^{1}$ (D)
}

Received: 12 February 2020 / Revised: 28 May 2020 / Accepted: 30 June 2020 / Published online: 13 July 2020

(c) The Author(s) 2020

\begin{abstract}
In this work red mud, a highly alkaline waste product generated during alumina production process, was valorised as a source of valuable metals and as an adsorbent material. A hydrometallurgical process was developed in order to recover titanium from red mud. By a leaching step with hydrochloric acid followed by ammonia precipitation and a further purification step by solvent extraction with Cyanex 301 using toluene as a solvent, quantitative recovery of titanium with a high purity level $(>95 \%)$ was achieved. Red mud adsorption properties were also tested for metal removal from aqueous solutions. The results showed the red mud potential in applications such as environmental remediation. The adsorption order was found to be: iron > lead > copper > manganese, zinc. Red mud can be thus potentially valorised both as a source of secondary titanium and as an adsorbent material, according to the principles of Circular Economy which promote waste reduction and the preservation of natural resources.
\end{abstract}

Keywords Adsorption $\cdot$ Circular economy $\cdot$ Hydrometallurgy $\cdot$ Red mud $\cdot$ Titanium

\section{Introduction}

Red mud is an industrial residue generated during the Bayer process of alumina production (Jones and Haynes 2011). For each ton of alumina, approximately 1-1.5 metric tons of red mud are produced (Kumar et al. 2006). About 140 million tons of bauxite residue are generated every year, which are normally placed in huge tailing ponds in contact with the atmosphere or discharged into the sea, often in a noncontrolled manner (Evans 2016; Power et al. 2011; Borra et al. 2015). The median particle size of red mud is normally in the range of 5-10 $\mu \mathrm{m}$; however, the breadth of particles

Editorial responsibility: Samareh Mirkia.

Electronic supplementary material The online version of this article (https://doi.org/10.1007/s13762-020-02835-5) contains supplementary material, which is available to authorized users.

D. Fontana

danilo.fontana@enea.it

1 ENEA, Italian National Agency for New Technologies, Energy and Sustainable Economic Development, Department for Sustainability, Via Anguillarese 301, 00123 Rome, Italy

2 Arpa Lazio, Via Giuseppe Saredo 52, 00173 Rome, Italy is both very broad ranging from coarse sandy grains about $1 \mathrm{~mm}$ in size down to sub-micron particles. This extremely fine structure, the high $\mathrm{pH}$ (about 12), and the presence of metals and metalloids make it an hazardous matrix for human health and the environment. For these reasons, there is a urgent need for better management strategies of this residue.

A number of studies are focused on red mud valorisation as a source of secondary raw materials (Alkan et al. 2017a, b; Lim and Shon 2015; Zhang et al. 2019; Borra et al. 2015; Rivera et al. 2018; Bonomi et al. 2018; Zhu et al. 2015). In the work of Borra et al. (2015), rare earths (REEs) leaching was investigated with different mineral acid; dissolution with hydrochloric acid ( $\mathrm{HCl}$ ) was high (about $80 \%$ ) compared to other acids, but significant co-dissolution of iron $(\mathrm{Fe})$ occurred (about $60 \%$ ). Sodium (Na) and calcium $(\mathrm{Ca})$ were completely dissolved during leaching, while dissolution of aluminium (Al), silicon ( $\mathrm{Si}$ ) and titanium (Ti) was between 30 and 50\%. In the work of Rivera et al. (2018), leaching of selected REEs by dry digestion method followed by water leaching was investigated. The authors found out that dissolution of silica is limited to less than $5 \mathrm{wt} \%$ by applying a two-step process based on dry digestion of red mud with $\mathrm{HCl}$ or sulphuric acid $\left(\mathrm{H}_{2} \mathrm{SO}_{4}\right)$ followed by water leaching. High extraction of the REEs were achieved with 
the HCl-based dry digestion method; the concentration in the leachate was limited to approximately $6-8 \mathrm{mg} \mathrm{L}^{-1}$, but it was increased by applying multi-stage circulation of the acid leaching solution. Alkan et al. (2017a) focused on Ti leaching from red mud and found out that sulphuric acid is the best candidate for the red mud treatment in terms of $\mathrm{Ti}$ leaching efficiency, which was $67.3 \%$ after $2 \mathrm{~h}$. In another work, the authors proposed a pretreatment step based on smelting of the red mud at $T=1500-1550{ }^{\circ} \mathrm{C}$ to improve the efficiencies of scandium $(\mathrm{Sc})$ and $\mathrm{Ti}$ with lower acid consumption; smelting allowed recovering Fe to the metal phase and concentrating other major and minor elements in the slag (Alkan et al. 2017b). In the work of Lim and Shon (2015), the effects of various parameters were investigated for the leaching of $\mathrm{Fe}, \mathrm{Al}$ and $\mathrm{Ti}$ from red mud. It was found that the ones which mostly influence the leaching efficiency were ultrasound power, acid concentration and reaction temperature and that the proper conditions are ultrasound power of $150 \mathrm{~W}$, sulphuric acid concentration of $6 \mathrm{~N}$, reaction temperature of $70{ }^{\circ} \mathrm{C}$, solid-to-liquid ratio of $2 \%$, and reaction time of $2 \mathrm{~h}$. Zhang et al. (2019) proposed an approach to selectively recover $\mathrm{Fe}$ and REEs from red mud through acid leaching with $\mathrm{HCl}$ proposed followed by solvent extraction with Aliquat 336. $\mathrm{HCl}$ was effective for efficiencies of most of the elements ( $\mathrm{Fe}, \mathrm{Al}, \mathrm{Sc}, \mathrm{La}, \mathrm{Ce}, \mathrm{Nd}$ and $\mathrm{Y}$ ); however, only $68.3 \% \mathrm{Ti}$ was leached. Aliquat 336 showed excellent extraction performance of $\mathrm{Fe}$ in chloride-rich solution while the loss of other metals was less than $10 \%$. In the work of Bonomi et al. 2018, red mud was directly leached using the Brønsted acidic ionic liquid 1-ethyl-3-methylimidazolium hydrogensulfate. High recovery yields of Sc (nearly 80\%) and $\mathrm{Ti}(90 \%)$, almost total dissolution of $\mathrm{Fe}$ and 30-40\% dissolution of $\mathrm{Al}$ and $\mathrm{Na}$ was achieved. Si and REEs dissolutions were found to be negligible, whereas $\mathrm{Ca}$ was dissolved and re-precipitated as $\mathrm{CaSO}_{4}$. Zhu et al. (2015) investigated the recovery of Ti with citric acid in sulphuric acid. The results show that citric acid increased Ti recovery (from 65 to $82 \%$ ) and decrease the consumption of sulphuric acid.

Red mud can be considered as an alternative to ex situ remediation process due to its capability to neutralise matrices with acidic $\mathrm{pH}$; given its high concentrations of $\mathrm{Al}, \mathrm{Fe}$, Ti and silica oxides and hydroxides, red mud may be developed as a cheap adsorbent for the removal of various ions from aqueous solution and soils (Rai et al. 2012; Wang et al. 2019). Surface modification of red mud by acid activation, alkali activation and heat treatment is often adopted in order to improve its adsorption capacity (Wang et al. 2019). In the work of Salim et al. (2018) the potential of red mud for nitrogen $(\mathrm{N})$ and phosphorus $(\mathrm{P})$ removal in petrochemical industry wastewater was investigated; the maximum adsorption of $\mathrm{N}$ and $\mathrm{P}$ was observed by acid treatment adsorbent (68.75\% and $63.16 \%$, respectively). Activated red mud, obtained by acid dissolution and ammonia treatment, was used as an adsorbent for chromium $(\mathrm{Cr})$, copper $(\mathrm{Cu})$ and lead $(\mathrm{Pb})$ removal from industrial effluents by Tsamo et al. (2018), while Duan et al. (2016) investigated the removal of cadmium (Cd) from aqueous solutions using red mud activated by $\mathrm{H}_{2} \mathrm{O}_{2}$.

In the present work, red mud was valorised both as a source of secondary raw materials and as an adsorbent material. This approach is in accordance with the principles of Circular Economy, which promote waste reduction and the development of processes where pressure on natural and freshwater resources as well as ecosystems is minimised (European Commission 2019). The research activity reported in this paper has been performed in the ENEA laboratory facilities (Rome, Italy) during year 2019.

\section{Materials and methods}

\section{Characterisation of red mud}

About $10 \mathrm{~kg}$ sample was collected from a settling tank at Eurallumina S.p.A. (Portovesme, Sardinia). Water content was determined by comparing two techniques: drying until constant weight in an oven at $T=40{ }^{\circ} \mathrm{C}$ and lyophilisation (lyophilisator LIO-5P with pump Edwards). In both cases, a certain amount of sample was weighted before and after the treatment and water content was determined from the weight difference.

After drying, sample was milled in a planetary mill (Retsch PM100) in order to homogenise it. Milling conditions were: 10 min milling time, $300 \mathrm{rpm}$ speed and rotation inversion every $2 \mathrm{~min}$ (with no interruption). This dried sample was used as starting materials for the following tests and defined in the text as 'initial sample'.

$\mathrm{pH}$ was determined according to the soils methodology (DM 13 September 1999), after contacting the dried sample with distilled water at $1 / 2.5$ solid-to-liquid $(\mathrm{S} / \mathrm{L}$ ) ratio under agitation for $2 \mathrm{~h}$ and subsequent sedimentation for $30 \mathrm{~min}$. $\mathrm{pH}$ measurements were performed by using a Thermo Orion Star A111 pH meter.

Organic and inorganic carbon was determined on 4 portions of the initial sample of about $30-40 \mathrm{mg}$ using a Shimadzu Total Organic Carbon (TOC) analyser (module for solids). Measurements were performed at two temperature values: $900{ }^{\circ} \mathrm{C}$ in order to determine the concentration of organic carbon (catalytic oxidation of $\mathrm{C}$ into $\mathrm{CO}_{2}$ ) and $200{ }^{\circ} \mathrm{C}$ to determine the inorganic carbon (samples was treated with phosphoric acid and inorganic $\mathrm{C}$ was determined as $\mathrm{CO}_{2}$ released). After lyophilisation and homogenization, sample was analysed through infrared (IR) spectrophotometer (Miracle 10 Shimadzu) in order to verify the presence of functional groups of the organic fraction. 
Sample was subjected to 45 scans with resolution $4 \mathrm{~cm}^{-1}$, in the range of frequencies $500-5000 \mathrm{~cm}^{-1}$.

Thermoanalysis was performed by using a thermobalance (Mettler-Toledo, TGA/DSC model). Samples were put into an aluminium crucible and subjected to the following temperature program: from 25 to $1400{ }^{\circ} \mathrm{C}$ at $5{ }^{\circ} \mathrm{C} \mathrm{min}{ }^{-1}$ rate and $80 \mathrm{~mL} \mathrm{~min}^{-1}$ air flow.

Chemical composition was investigated by scanning electron microscopy/energy-dispersive X-ray analysis (SEM/ EDS).

Metal content was determined by mineralisation using a Milestone S.r.l. START D Microwave Digestion System. About 50, 100, 150 and $200 \mathrm{mg}$ sample were treated with $8 \mathrm{~mL}$ nitric acid $\left(\mathrm{HNO}_{3}\right)(65 \mathrm{wt} \%)$ and aqua regia. The best results were obtained at aqua regia $\mathrm{S} / \mathrm{L}=1 / 40$; the solutions were analysed with atomic absorption spectroscopy (AAS, Shimadzu 6300) and microwave plasma-atomic emission spectrometry (MP-AES, Agilent 4100). Before the analysis, all solutions were centrifuged and separated from the solid by vacuum filtration by using paper filters $(0.45 \mu \mathrm{m})$. The insoluble residue was collected from the filter and subjected to a second filtration; the analyses showed that the first solubilisation brought into solution $99 \mathrm{wt} \%$ of the soluble chemical species.

In this work, all experiments were carried out at least in quadruplicate as a check on the experimental technique and precision, and the experimental results agreed within $\pm 5 \%$ as a percentage error. This error was evaluated considering the total experimental error (systematic plus random error).

\section{Titanium recovery by hydrometallurgy}

Leaching tests were performed with different leaching agents: $\mathrm{HNO}_{3}, \mathrm{H}_{2} \mathrm{SO}_{4}, \mathrm{HCl}$, EDTA and aqua regia. Samples were contacted with the leaching agent in plastic bottles placed on a horizontal mechanical shaker. The following operative conditions were used for the leaching: $\mathrm{P}=\mathrm{P}$ atm, room temperature $\left(T=25^{\circ} \mathrm{C}\right), \mathrm{S} / \mathrm{L}=1 / 10$, agitation speed $=150 \mathrm{rpm}, t=24 \mathrm{~h}$. The liquid phase was afterwards separated from the solid residue by centrifugation $(t=10 \mathrm{~min}, 4000 \mathrm{rpm}$. The supernatant was filtered $(0.45 \mu \mathrm{m})$ in order to determine the leaching efficiency $E_{\mathrm{L}}(\%)$, which was calculated according to Eq. (1):

$$
E_{\mathrm{L}}(\%)=\frac{m_{\mathrm{L}}}{m_{0}} \cdot 100
$$

where $m_{\mathrm{L}}$ is the mass of the dissolved metal and $m_{0}$ is the mass of metal in the initial sample.

The insoluble residues were washed, dried in an oven at $T=45{ }^{\circ} \mathrm{C}$ for $24 \mathrm{~h}$ and weighted. In order to identify the optimal conditions for the selective separation of $\mathrm{Ti}$, tests on a solution with known concentration of $\mathrm{Fe}\left(6000 \mathrm{mg} \mathrm{L}^{-1}\right)$ and
$\mathrm{Ti}$ (500 mg L ${ }^{-1}$ ) were performed; these concentration values were selected because they resembled the stoichiometric ratios of the real leachate.

Precipitation tests were performed with several precipitating agents in stoichiometric excess, such as oxalic acid, acetic acid, sulphuric acid, tartaric acid, thiosulfate, iodide and ammonia. The solution was afterwards centrifuged, and the supernatant was analysed by AAS and MP-AES in order to determine the precipitation percentage.

The obtained precipitate was separated from the solution by centrifugation and then re-dissolved in $\mathrm{HCl} 0.10 \mathrm{~mol} \mathrm{~L}^{-1}$. The aqueous phase was then contacted with an organic phase constituted by $0.1 \mathrm{~mol} \mathrm{~L}^{-1}$ Cyanex 301 (structural formula shown in Fig. S1) in limonene for 20 min (Deep et al. 2001). The organic/aqueous (O/A) volume ratio was $1 / 1$. Solvent extraction (SX) tests were performed in glass vials placed on a mechanical horizontal shaker at room temperature $\left(T=25^{\circ} \mathrm{C}\right)$. The two phases were afterwards separated and characterised in order to determine the extraction efficiency. The loaded organic phase was then contacted with a fresh aqueous phase constituted by $3 \% \mathrm{H}_{2} \mathrm{O}_{2}+0.5 \mathrm{~mol} \mathrm{~L}^{-1} \mathrm{H}_{2} \mathrm{SO}_{4}$ during the stripping tests, which were performed at room temperature $\left(T=25^{\circ} \mathrm{C}\right.$ ) for $5 \mathrm{~min}$ (repeated two times) and at $\mathrm{O} / \mathrm{A}=2 / 1$.

\section{Study of the adsorption capacity of red mud}

The possibility to use red mud as adsorbent material was here studied. Because of its high alkalinity and the presence of adsorbed sodium, the sample was first washed until neutral $\mathrm{pH}$ with distilled water and then dried at $\mathrm{T}=80^{\circ} \mathrm{C}$ until constant weight.

Adsorption tests were performed in batch by contacting known amount of sample with solutions with known concentration of $\mathrm{Fe}, \mathrm{Pb}, \mathrm{Cu}, \mathrm{Mn}$ and $\mathrm{Zn}$, selected by taking into account their significant presence in contaminated environmental systems, their different chemical properties (charge, mass, iodic radius) and their origin (mineralogical for $\mathrm{Mn}$ and $\mathrm{Fe}$ and anthropic for $\mathrm{Pb}, \mathrm{Cu}$ and $\mathrm{Zn}$ ). Adsorption tests were performed in beakers and under agitation (through magnetic stirrer), at $\mathrm{P}=\mathrm{P}$ atm and room temperature $\left(T=25^{\circ} \mathrm{C}\right)$, by varying the contact time $(t=1,3,6,24 \mathrm{~h})$, the metal concentration in the feed $\left(100,1000\right.$ and $4000 \mathrm{mg} \mathrm{L}^{-1}$ solutions $)$ and the $S / L$ ratio $(S / L=1 / 10$ and $1 / 20)$. Samples were afterwards centrifuged (Nuve NF800 centrifuge, $t=5 \mathrm{~min}, 4000 \mathrm{rpm}$ ); the supernatant was afterwards filtered by using paper filters $(0.45 \mu \mathrm{m})$ and analysed by AAs and MP-AES. 


\section{Results and discussion}

\section{Characterisation}

Water content in the red mud sample obtained by dehydration method and by lyophilisation was $31.5 \pm 0.5 \mathrm{wt} \%$ and $31.0 \pm 0.5 \mathrm{wt} \%$, respectively. A good reliability with respect to the error on the specific technique and good correspondence between the two methods was thus observed.

Organic and inorganic carbon content was $0.54 \% \pm 0.01$ $\mathrm{wt} \%$ and $0.40 \% \pm 0.01 \mathrm{wt} \%$, respectively, which showed the low carbon content in the matrix. The organic component might be due to interaction with biosphere in the decantation tanks, while the inorganic content might be due to the carbonation process, which is typical of basic matrices in contact with atmospheric $\mathrm{CO}_{2}$.

$\mathrm{pH}$ was $8.85 \pm 0.02$, showing the partial stabilisation of the mud. The red mud sample was, in fact, produced in year 2009 and over time it underwent a natural carbonation process due to the contact with atmospheric $\mathrm{CO}_{2}$, which reduced the initial $\mathrm{pH}$.

The thermogram (Fig. 1) shows a weight loss of about $9 \%$ in the temperature range $25-700{ }^{\circ} \mathrm{C}$ due to the loss of the interstitial water (first part of the temperature range until about $150{ }^{\circ} \mathrm{C}$ ) and of the chemically bounded water $\left(150-700{ }^{\circ} \mathrm{C}\right)$; the loss of about $10 \%$ in the range $600-1250{ }^{\circ} \mathrm{C}$ is instead due to calcite and aluminium silicocarbonates decomposition (Borra et al. 2015).
Sample shows a wide particle size distribution, from hundreds $\mu \mathrm{m}$ until few dozen nm (Figure S2). As shown in Figure S3-4, several elements are present in the sample. EDS analysis showed the presence of $\mathrm{O}, \mathrm{Al}, \mathrm{Na}, \mathrm{Ca}, \mathrm{Ti}, \mathrm{Mg}$, $\mathrm{Si}, \mathrm{S}, \mathrm{Cl}, \mathrm{K}, \mathrm{Fe}$ and traces of $\mathrm{Mn}, \mathrm{V}, \mathrm{Cu}, \mathrm{Zn}, \mathrm{Ba}$ (associated with a $\mathrm{S}$ ). In some particles $\mathrm{Zr}$ was found (associated with $\mathrm{Si})$ and $\mathrm{Ce}$.

Metal composition determined after dissolution in aqua regia is reported in Table 1 . These tests report the error (range) calculated by taking the difference between the maximum and minimum values in the data set divided by two. It

Table 1 Concentration values $\left(\mathrm{mg} \mathrm{g}^{-1}\right)$ after mineralization with aqua regia and nitric acid $(65 \mathrm{wt} \%)$ at $\mathrm{S} / \mathrm{L}=1 / 40$

\begin{tabular}{lll}
\hline Element & Aqua regia & $\mathrm{HNO}_{3}$ \\
\hline $\mathrm{Mn}$ & $0.40 \pm 0.01$ & $0.29 \pm 0.02$ \\
$\mathrm{Ga}$ & $0.28 \pm 0.01$ & $0.21 \pm 0.01$ \\
$\mathrm{Ba}$ & $0.17 \pm 0.01$ & $0.07 \pm 0.01$ \\
$\mathrm{Sr}$ & $0.13 \pm 0.01$ & $0.060 \pm 0.008$ \\
$\mathrm{~V}$ & $0.80 \pm 0.01$ & $0.40 \pm 0.01$ \\
$\mathrm{Fe}$ & $159 \pm 3$ & $157 \pm 7$ \\
$\mathrm{Al}$ & $105 \pm 2$ & $104 \pm 8$ \\
$\mathrm{Ca}$ & $38 \pm 1$ & $34.6 \pm 0.7$ \\
$\mathrm{Ti}$ & $17.0 \pm 0.4$ & $15.0 \pm 0.4$ \\
$\mathrm{Mg}$ & $4.7 \pm 0.1$ & $4.1 \pm 0.2$ \\
$\mathrm{Cr}$ & $1.6 \pm 0.1$ & $1.4 \pm 0.1$ \\
$\mathrm{Si}$ & $83 \pm 2$ & \\
\hline
\end{tabular}

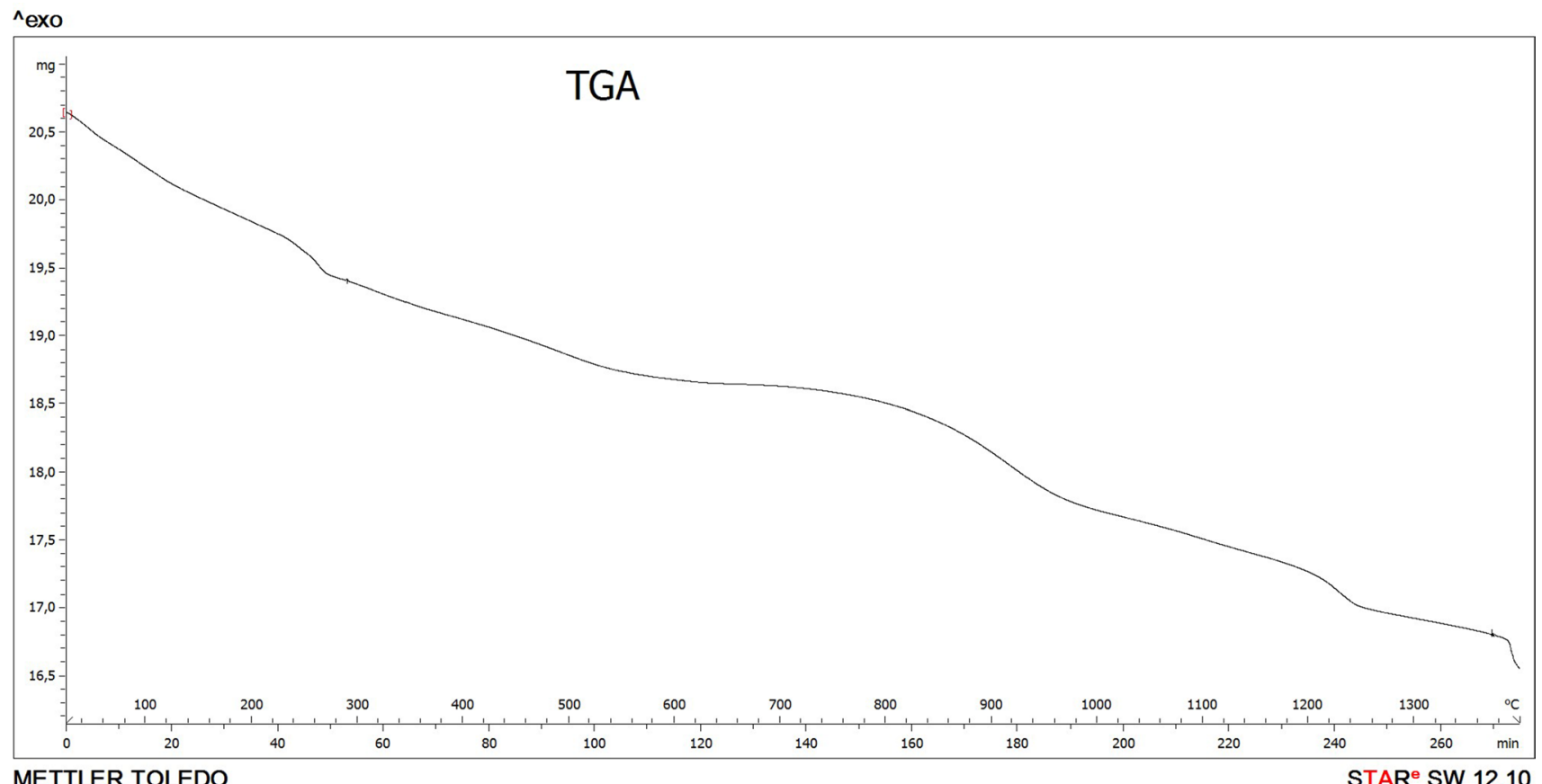

Fig. 1 Thermogravimetric analysis performed through TGA/DSC 
Table 2 Concentration values in the initial sample $\left(\mathrm{mg} \mathrm{g}^{-1}\right)$ obtained after sample dissolution with different leaching agents at $\mathrm{S} / \mathrm{L}=1 / 10$

\begin{tabular}{llllll}
\hline Element & $\begin{array}{l}\mathrm{HNO}_{3} 65 \\
\mathrm{wt} \%\end{array}$ & $\begin{array}{l}\mathrm{HCl} 37 \\
\mathrm{wt} \%\end{array}$ & $\begin{array}{l}\mathrm{H}_{2} \mathrm{SO}_{4} 96 \\
\mathrm{wt} \%\end{array}$ & aqua regia & EDTA \\
\hline $\mathrm{Fe}$ & 8.4 & 156 & 104.3 & 140.5 & 0.5 \\
$\mathrm{Al}$ & 76.1 & 82 & 82.6 & 72.7 & 30.2 \\
$\mathrm{Ca}$ & 28 & 27 & 18.2 & 22.3 & 25.9 \\
$\mathrm{Ti}$ & 7.5 & 16 & 14.9 & 13.9 & 0.2 \\
$\mathrm{Mg}$ & 3.6 & 4.2 & 3.6 & 3.8 & 0.9 \\
$\mathrm{Cr}$ & 0.2 & 1.3 & 0.6 & 1.2 & 0.01 \\
$\mathrm{~V}$ & 0.3 & 0.8 & 0.6 & 0.7 & 0.1 \\
$\mathrm{Mn}$ & 0.4 & 0.4 & 0.2 & 0.3 & 0.1 \\
$\mathrm{Ga}$ & 0.1 & 0.3 & 0.2 & 0.3 & 0.02 \\
$\mathrm{Ba}$ & 0.1 & 0.1 & 0.1 & 0.1 & 0.02 \\
$\mathrm{Sr}$ & 0.1 & 0.1 & 0.03 & 0.1 & 0.01 \\
$\mathrm{Ni}$ & $<0.01$ & 0.02 & 0.02 & 0.02 & 0.01 \\
$\mathrm{Cu}$ & 0.01 & $<0.0012$ & $<0.01$ & $<0.01$ & $<0.01$ \\
$\mathrm{Si}$ & 0.1 & $<0.012$ & $<0.01$ & $<0.01$ & 11.8 \\
\hline
\end{tabular}

was found that $\mathrm{Fe}, \mathrm{Al}, \mathrm{Ca}$ and $\mathrm{Ti}$ are the most abundant elements. Y, Zn, Cd, Si, Pb, Pd, Tb, Pr, Nd, Sb, Dy, Sm, Co, B, As, Ir, Pt, Au, Ag, Sn concentration resulted to be $<0.01 \%$. Aqua regia allowed solubilizing a higher amount of Ti, V, $\mathrm{Mn}, \mathrm{Ba}, \mathrm{Sr}$ and was thus selected as the optimal one for the mineralization step. In particular, Ti content was found to be $17 \mathrm{mg} \mathrm{g}^{-1}$, corresponding to $1.7 \mathrm{wt} \%$.

\section{Titanium recovery by hydrometallurgy}

The relatively low content of $\mathrm{Ti}$ found in the selected red mud sample (1.7 wt\%) might be significantly higher in red mud with different origin: it has been reported that $\mathrm{TiO}_{2}$ concentration can be up to $25 \mathrm{wt} \%$ (Rai et al. 2012). For this reason, it is interesting to evaluate its recovery options. This was done by employing hydrometallurgical techniques, which normally consist in a leaching step followed by a separation/purification step aimed at metal recovery.

As shown in Table 2, the best leaching agent resulted to be $\mathrm{HCl}(\mathrm{S} / \mathrm{L}=1 / 10)$. Several tests were then performed with different $\mathrm{HCl}$ concentration values (Table 3 ) to identify the most effective one, by keeping constant the $\mathrm{S} / \mathrm{L}$ at 1/10. It was found that $12 \mathrm{~mol} \mathrm{~L}^{-1} \mathrm{HCl}$ allowed solubilising the highest amount of metals and especially $\mathrm{Ti}$.

$\mathrm{Ti}$ recovery from the $\mathrm{HCl}$ leachate was then investigated by precipitation. From the experimental tests performed with a stoichiometric excess of precipitating agent it was found that thiosulfate allowed precipitating only part of $\mathrm{Ti}$ and $\mathrm{Fe}$, while quantitative precipitation was achieved with ammonia; the other precipitating agents were not effective (Table 4). Further tests were thus performed to verify the effect of $\mathrm{pH}$ on the other chemical species due to ammonia
Table 3 Leaching efficiency (\%) using $\mathrm{HCl}$ as a function of the concentration at $\mathrm{S} / \mathrm{L}=1 / 10$

\begin{tabular}{|c|c|c|c|}
\hline \multirow[b]{2}{*}{ Element } & \multicolumn{3}{|c|}{$\begin{array}{l}\mathrm{HCl} \text { concentra- } \\
\text { tion }\left(\mathrm{mol} \mathrm{L}^{-1}\right)\end{array}$} \\
\hline & 12 & 6 & 1.2 \\
\hline $\mathrm{Fe}$ & 98 & 97 & 1 \\
\hline $\mathrm{Al}$ & 79 & 88 & 69 \\
\hline $\mathrm{Ca}$ & 71 & 66 & 58 \\
\hline $\mathrm{Ti}$ & 95 & 71 & 7 \\
\hline $\mathrm{Mg}$ & 89 & 78 & 65 \\
\hline $\mathrm{Cr}$ & 81 & 65 & 6 \\
\hline $\mathrm{V}$ & 100 & 89 & 6 \\
\hline $\mathrm{Mn}$ & 100 & 75 & 15 \\
\hline $\mathrm{Ga}$ & 100 & 68 & 20 \\
\hline $\mathrm{Ba}$ & 59 & 59 & 41 \\
\hline $\mathrm{Sr}$ & 100 & 100 & 100 \\
\hline
\end{tabular}

Table $4 \mathrm{Fe}$ and Ti precipitation efficiency (\%) from the $\mathrm{HCl}$ leachate as a function of the precipitating agent

\begin{tabular}{lrr}
\hline Precipitating agent & $\mathrm{Fe}$ & \multicolumn{2}{c}{$\mathrm{Ti}$} \\
\hline Oxalic acid & 0 & 0 \\
Acetic acid & 0 & 0 \\
Sulphuric acid & 0 & 0 \\
Tartaric acid & 0 & 0 \\
Thiosulfate & 20 & 65 \\
Iodide & 0 & 0 \\
Ammonia & 100 & 100 \\
\hline
\end{tabular}

Fig. 2 Percentage precipitation as a function of $\mathrm{pH}$. Initial concentration values: $[\mathrm{Fe}]=5150 \mathrm{mg} \mathrm{L}^{-1},[\mathrm{Al}]=2880 \mathrm{mg} \mathrm{L}^{-1},[\mathrm{Ca}]=1302 \mathrm{mg}$ $\mathrm{L}^{-1},[\mathrm{Ti}]=616 \mathrm{mg} \mathrm{L}^{-1},[\mathrm{Mg}]=147 \mathrm{mg} \mathrm{L}^{-1},[\mathrm{Cr}]=45 \mathrm{mg} \mathrm{L}^{-1}$, $[\mathrm{Mn}]=14 \mathrm{mg} \mathrm{L}^{-1},[\mathrm{Ga}]=12 \mathrm{mg} \mathrm{L}^{-1},[\mathrm{~V}]=32 \mathrm{mg} \mathrm{L}^{-1}$

addition (Fig. 2). It was found that at $\mathrm{pH} 2.2 \mathrm{Fe}$ and $\mathrm{Ti}$ quantitatively precipitated, while other elements such as $\mathrm{Ca}$ and $\mathrm{Al}$ (which are present in high concentration) remained in solution. Therefore, ammonia precipitation at pH 2.2 can be considered an effective method for the separation/purification of $\mathrm{Fe}$ and $\mathrm{Ti}$. $\mathrm{V}$ co-precipitated with 
$\mathrm{Fe}$ and $\mathrm{Ti}$; however, the amount of precipitated metal was extremely low when compared to the other two elements.

The obtained precipitated was re-dissolved in $\mathrm{HCl}$ and the leachate was subjected to a separation step by solvent extraction (Table 5). From the experimental results, it was found that $\mathrm{Ti} / \mathrm{Fe}$ separation is feasible. Even though both elements are extracted in the organic phase (Cyanex 301 in limonene), during the back-extraction step with $3 \% \mathrm{H}_{2} \mathrm{O}_{2}+0.5 \mathrm{~mol} \mathrm{~L}^{-1}$ $\mathrm{H}_{2} \mathrm{SO}_{4}, 95 \% \mathrm{Fe}$ remains in the organic phase, while there is a repartition of Ti: $50 \%$ remains in the organic phase and $50 \%$ in the aqueous phase. To quantitatively recover $\mathrm{Ti}$, it is then sufficient to repeat the stripping step more than one time (multiple stages).

Figure 3 shows the flow sheet of Ti recovery process. This is based on three main steps aimed at (1) dissolving the element of interest by leaching with mineral acids and at their recovery/purification by precipitation (2) and solvent extraction/stripping (3). The process allowed to obtain a product with high purity: even though $\mathrm{Fe}$ behaves like $\mathrm{Ti}$ and it is co-extracted in the organic phase, it can be easily separated in the back-extraction step.

Table $5 \mathrm{Fe}$ and Ti repartition (\%) in the organic and aqueous phase during solvent extraction and stripping

\begin{tabular}{lllc}
\hline & Element & Organic phase & $\begin{array}{l}\text { Aqueous } \\
\text { phase }\end{array}$ \\
\hline SX & Fe & 99 & 1 \\
& $\mathrm{Ti}$ & 99 & 1 \\
Stripping & $\mathrm{Fe}$ & 95 & 5 \\
& $\mathrm{Ti}$ & 50 & 50 \\
\hline
\end{tabular}

\section{Study of the adsorption capacity of red mud}

In paragraph 3.3 the results of the adsorption tests performed on red mud samples are reported. As shown in Table 6, when using $100 \mathrm{mg} \mathrm{L}^{-1}$ solutions as a feed, $100 \%$ adsorption percentage can be achieved for each element without selectivity; this is because the sample adsorbed lower quantities compared to its adsorption capacity. When $1000 \mathrm{mg} \mathrm{L}^{-1}$ solutions are used as feed, quantitative adsorption of $\mathrm{Pb}, \mathrm{Cu}$ and $\mathrm{Fe}$ is obtained already after $1 \mathrm{~h}$ and only small amounts of $\mathrm{Zn}$ and $\mathrm{Mn}$ are adsorbed after $24 \mathrm{~h}$. By increasing the feed concentration up to $4000 \mathrm{mg} \mathrm{L}^{-1}$ and by decreasing the $\mathrm{S} / \mathrm{L}$ ratio to $1 / 20$, it was found that more than $70 \mathrm{mg} \mathrm{g}^{-1}$ $\mathrm{Fe}$ and $\mathrm{Pb}$ are adsorbed, if simultaneously present, about $9 \mathrm{mg} \mathrm{g}^{-1} \mathrm{Cu}$ and $\leq 6 \mathrm{mg} \mathrm{g}^{-1} \mathrm{Zn}$ and Mn (Table 7). A selectivity was thus observed, which shows a different adsorption capacity according to the order: $\mathrm{Fe}>\mathrm{Pb}>\mathrm{Cu}>\mathrm{Mn}, \mathrm{Zn}$ (as mmol g${ }^{-1}$ ).

These results suggest the possibility to use red mud as an adsorbent material in an integrated process aimed at a full potential usage of this industrial residue: after Ti recovery from the initial sample, the residue generated from the leaching step (see Fig. 3) can be used as adsorbent material for waste water treatment, thus avoiding its landfilling/ incineration.

\section{Conclusion}

In this work, red mud was valorised as a source of secondary raw materials and also as an adsorbent material. Red mud characterisation showed the presence of high value-added
Fig. 3 Ti recovery process flow-sheet
Leachate

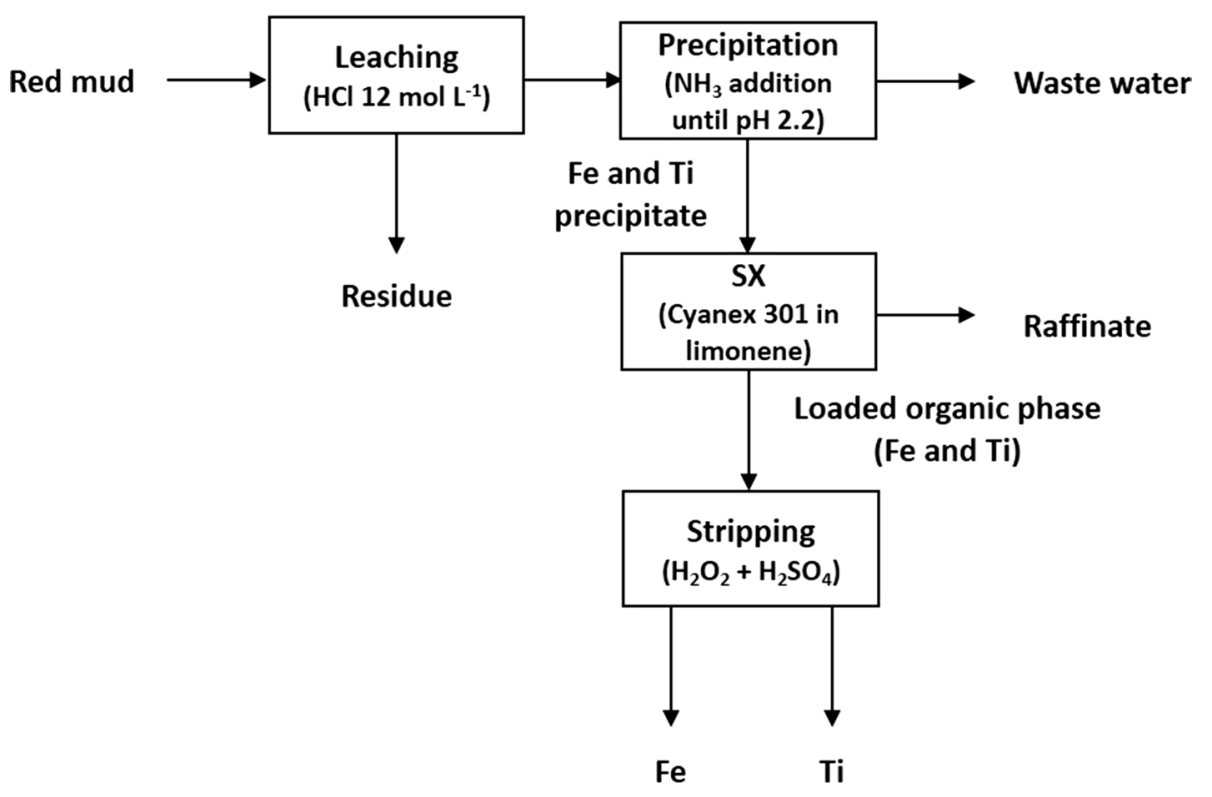


Table 6 Metal adsorption percentage from multi-element solutions of $100 \mathrm{mg} \mathrm{L}^{-1}$ and $1000 \mathrm{mg} \mathrm{L}^{-1}(\mathrm{~S} / \mathrm{L}=1 / 10)$

\begin{tabular}{|c|c|c|c|c|c|}
\hline \multirow[t]{2}{*}{ Element } & \multirow{2}{*}{$\begin{array}{l}\text { Contact } \\
\text { time }(\mathrm{h})\end{array}$} & \multicolumn{2}{|c|}{$100 \mathrm{mg} \mathrm{L}^{-1}$ solution } & \multicolumn{2}{|c|}{$1000 \mathrm{mg} \mathrm{L}^{-1}$ solution } \\
\hline & & Adsorption \% & $\begin{array}{l}\text { Metal adsorbed/g red } \\
\text { mud }\left(\mathrm{mg} \mathrm{g}^{-1}\right)\end{array}$ & Adsorption (\%) & $\begin{array}{l}\text { Metal adsorbed/g } \\
\text { red mud }\left(\mathrm{mg} \mathrm{g}^{-1}\right)\end{array}$ \\
\hline \multirow[t]{4}{*}{$\mathrm{Cu}$} & 1 & 100 & 1 & 91 & 8.1 \\
\hline & 3 & 100 & 1 & 95 & 8.8 \\
\hline & 6 & 100 & 1 & 97 & 8.8 \\
\hline & 24 & 100 & 1 & 99 & 8.8 \\
\hline \multirow[t]{4}{*}{$\mathrm{Pb}$} & 1 & 100 & 1 & 100 & 10.7 \\
\hline & 3 & 100 & 1 & 100 & 11.1 \\
\hline & 6 & 100 & 1 & 100 & 11 \\
\hline & 24 & 100 & 1 & 100 & 10.8 \\
\hline \multirow[t]{4}{*}{$\mathrm{Fe}$} & 1 & 100 & 1 & 100 & 6.9 \\
\hline & 3 & 100 & 1 & 100 & 7.3 \\
\hline & 6 & 99 & 1 & 100 & 7 \\
\hline & 24 & 99 & 1 & 100 & 7.1 \\
\hline \multirow[t]{4}{*}{$\mathrm{Mn}$} & 1 & 96 & 1 & 6 & 0.6 \\
\hline & 3 & 96 & 1 & 0 & 0.1 \\
\hline & 6 & 98 & 1 & 4 & 0.3 \\
\hline & 24 & 99 & 1 & 11 & 1.2 \\
\hline \multirow[t]{4}{*}{$\mathrm{Zn}$} & 1 & 100 & 1 & 0 & 0 \\
\hline & 3 & 100 & 1 & 4 & 0.4 \\
\hline & 6 & 100 & 1 & 20 & 1.5 \\
\hline & 24 & 100 & 1 & 42 & 3.4 \\
\hline
\end{tabular}

Table 7 Metals adsorption from $4000 \mathrm{mg} \mathrm{L}^{-1}$ solution of $\mathrm{Pb}, \mathrm{Cu}, \mathrm{Zn}$, $\mathrm{Fe}, \mathrm{Mn}(t=24 \mathrm{~h}, \mathrm{~S} / \mathrm{L}=1 / 20)$

\begin{tabular}{llll}
\hline Element & $\begin{array}{l}\text { Adsorption } \\
(\%)\end{array}$ & $\begin{array}{l}\text { Metal adsorbed/g red } \\
\text { mud }\left(\mathrm{mg} \mathrm{g}^{-1}\right)\end{array}$ & $\begin{array}{l}\text { Metal adsorbed/g } \\
\text { red mud } \\
\left(\mathrm{mmol} \mathrm{g}^{-1}\right)\end{array}$ \\
\hline $\mathrm{Fe}$ & 95 & 76 & 1.36 \\
$\mathrm{~Pb}$ & 88 & 70 & 0.34 \\
$\mathrm{Cu}$ & 11 & 9 & 0.14 \\
$\mathrm{Mn}$ & 6 & 5 & 0.20 \\
$\mathrm{Zn}$ & 1 & 0.8 & 0.01 \\
\hline
\end{tabular}

elements such as $\mathrm{Ti}(1.7 \mathrm{wt} \%)$ and a hydrometallurgical process was here developed for its recovery. It was found that leaching with $\mathrm{HCl}$ followed by ammonia precipitation and solvent extraction with Cyanex 301 allowed quantitative recovery of Ti with purity $>95 \%$. The adsorption tests showed that that red mud has a high adsorption capacity for $\mathrm{Fe}\left(76 \mathrm{mg} \mathrm{g}^{-1}\right), \mathrm{Pb}\left(70 \mathrm{mg} \mathrm{g}^{-1}\right)$ and $\mathrm{Cu}\left(9 \mathrm{mg} \mathrm{g}^{-1}\right)$ while $\mathrm{Zn}$ and $\mathrm{Mn}$ are adsorbed to a lower extent. Moreover, there is a selectivity in the adsorption process when these elements are simultaneously present in solution, in particular the adsorption order is: $\mathrm{Fe}>\mathrm{Pb}>\mathrm{Cu}>\mathrm{Mn}, \mathrm{Zn}$. Red mud valorisation, besides reducing the volume of waste to be disposed of and thus containing the environmental pollution, offers the opportunity to recover critical raw materials. This is in accordance with the principles of Circular Economy, which promote waste reduction and the development of treatment processes able to meet social, environmental and economic needs, by ensuring also the preservation of natural resources.

Acknowledgements Open access funding provided by Ente per le Nuove Tecnologie, l'Energia e l'Ambiente within the CRUI-CARE Agreement. The authors acknowledge Eurallumina S.p.A. (Portovesme, Sardinia) for providing the red mud sample.

Authors' contributions All authors contributed equally to the work.

Funding The Authors received no specific funding for this work.

Availability of data and material Not applicable.

\section{Compliance with ethical standards}

Conflict of interest There are no conflicts of interest/competing interests to declare.

Ethical approval This article does not contain any studies with human participants or animals performed by any of the authors.

Code availability Not applicable.

Open Access This article is licensed under a Creative Commons Attribution 4.0 International License, which permits use, sharing, adaptation, distribution and reproduction in any medium or format, as long as you give appropriate credit to the original author(s) and the source, provide a link to the Creative Commons licence, and indicate if changes 
were made. The images or other third party material in this article are included in the article's Creative Commons licence, unless indicated otherwise in a credit line to the material. If material is not included in the article's Creative Commons licence and your intended use is not permitted by statutory regulation or exceeds the permitted use, you will need to obtain permission directly from the copyright holder. To view a copy of this licence, visit http://creativecommons.org/licenses/by/4.0/.

\section{References}

Alkan G, Xakalashe B, Yagmurlu B, Kaussen F, Friedrich B (2017a) Conditioning of red mud for subsequent titanium and scandium recovery-a conceptual design study. World Metall Erzmetall 70:5-12

Alkan G, Schier C, Gronen L, Stopic S, Friedrich B (2017b) A mineralogical assessment on residues after acidic leaching of bauxite residue (red mud) for titanium recovery. Metals 7:1-11

Bonomi C, Alexandri A, Johannes Vind J, Panagiotopoulou A, Tsakiridis P, Panias D (2018) Scandium and titanium recovery from bauxite residue by direct leaching with a brønsted acidic ionic liquid. Metals 8:2-17

Borra CR, Pontikes Y, Binnemans K, Van Gerven T (2015) Leaching of rare earth from bauxite residue (red mud). Miner Eng 76:20-27

Deep A, Malik P, Gupta B (2001) Extraction and separation of Ti(IV) using thiophosphinic acids and its recovery from ilmenite and red mud. Sep Sci Technol 36:671-685

DM 13/09/1999. Approvazione dei Metodi ufficiali di analisi chimica del suolo

Duan F, Chen C, Zhao X, Yang Y, Liu X, Qin Y (2016) Water-compatible surface molecularly imprinted polymers with synergy of bi-functional monomers for enhanced selective adsorption of bisphenol a from aqueous solution. Environ Sci-Nano 3:213-222

European Commission (2019) Report from the Commission to the European Parliament, the Council, the European Economic and Social Committee and the Committee of the Regions on the Implementation of the Circular Economy Action Plan
Evans K (2016) The history, challenges, and new developments in the management and use of bauxite residue. J Sustain Metall 2:316-331

Jones BEH, Haynes RJ (2011) Bauxite processing residue: a critical review of its formation, properties, storage, and revegetation. Crit Rev Env Sci Tec 41:271-315

Kumar S, Kumar R, Bandopadhyay A (2006) Innovative methodologies for the utilisation of wastes from metallurgical and allied industries. Resour Conserv Recy 48:301-314

Lim KH, Shon BH (2015) Metal components (Fe, Al, and Ti) recovery from red mud by sulfuric acid leaching assisted with ultrasonic waves. Int J Emerging Technol Adv Eng 5:25-32

Power G, Gräfe M, Klauber C (2011) Bauxite residue issues: I. Current management, disposal and storage practices. Hydrometallurgy 108:33-45

Rai S, Wasewar KL, Mukhopadhyay J, Yoo CK, Uslu H (2012) Neutralization and utilization of red mud for its better waste management. Arch Environ SCI 6:13-33

Rivera RM, Ulenaers B, Ounoughene G, Binnemans K, Van Gerven T (2018) Extraction of rare earths from bauxite residue (red mud) by dry digestion followed by water leaching. Miner Eng 119:82-92

Salim NAM, Ajit A, Naila A, Sulaiman AZ (2018) Potential of Red mud as an adsorbent for nitrogen and phosphorous removal in the petrochemical industry wastewater. IJWWT 4:1-10

Tsamo C, Djomou Djonga PN, Dangwang Dikdim JM, Kamga R (2018) Kinetic and equilibrium studies of $\mathrm{Cr}(\mathrm{VI}), \mathrm{Cu}(\mathrm{II})$ and $\mathrm{Pb}$ (II) removal from aqueous solution using red mud, a low-cost adsorbent. Arab J Sci Eng 43:2353-2368

Wang L, Hu G, Lyu F, Yue T, Tang H, Han H, Yang Y, Liu R, Sun W (2019) Application of red mud in wastewater treatment. Minerals 9:1-22

Zhang XK, Zhou KG, Chen W, Lei QY, Huang Y, Peng CH (2019) Recovery of iron and rare earth elements from red mud through an acid leaching-stepwise extraction approach. J Cent South Univ 26:458-466

Zhu XB, Li W, Guan XM (2015) Kinetics of titanium leaching with citric acid in sulfuric acid from red mud. Trans Nonferrous Met Soc China 25:3139-3145 